\title{
Thinking Maps to Promote Critical Thinking through the Teaching of Literature in the ESL Context
}

\author{
Ainon Omar \\ Sultan Idris Education University, Malaysia \\ e-mail:ainon@fbk.upsi.edu.my \\ Intan Safinas Mohd. Ariff Albakri \\ Sultan Idris Education University, Malaysia \\ e-mail:safinas@fbk.upsi.edu.my
}

\begin{abstract}
:
The Malaysian education system has emphasized on the importance of producing students as thinking individuals in order to survive in the global era today. The $i$ Think program which was introduced in schools consists of eight cognitive teaching tools known as thinking maps that teachers can use to mediate students' thinking, learning, and promote metacognitive behaviours in their lessons. The purpose of this qualitative research study was to determine whether the teachers' implementation of the Thinking maps promoted critical thinking during the teaching of Literature in the ESL classroom. This case-study was conducted in a secondary school which was one of the pioneer schools selected by the Ministry of Education to implement the thinking maps in the teaching and learning of English language. Data were collected through observations, interviews and field notes. The findings revealed that the teachers were able to engage students to think critically through the use of the thinking maps during their literature lessons. The teachers also employed the Reader-Response strategies to complement the thinking maps in promoting critical thinking in the teaching of literature.
\end{abstract}

Keywords: i-Think program, critical thinking skills, English literature, thinking maps 


\section{Introduction}

The i-Think Program is an effort to help create a new culture of thinking in schools by fostering higher order thinking skills, nurturing a culture of lifelong learning, skilled in solving problems and working to generate creative solutions among school children. The i-Think program is adopted by the Ministry of Education to produce the next generation of innovators with the ability to include some elements of thinking skills which includes critical, creative, innovative and analytical skills in preparation to adapt and cope with the challenges of the $21^{\text {st }}$ century and beyond (Amin Senin, 2013). The National Education Blueprint (PPPM) 2013-2025 emphasizes the concept of high level thinking skills which is capable of producing the next generation to have critical and creative thinking skills. Generally, based on the Bloom taxonomy, higher order thinking skills (HOTS) or critical thinking refers to four top level thinking skills which are application, analysis, evaluation, and creation (Amin Senin, 2013). In this context, HOTS and critical thinking are used interchangeably as they refer to the same thinking skills. The issue of i-Think Program has been widely discussed and debated, especially by educators and education leaders (Zabani Darus, 2012 ; Amin Senin, 2013) and among the questions that often arise in connection with this issue is how the i-Think program can be applied to students in learning English language?

In the Malaysian Education system, the teaching of literature has been incorporated into the English language syllabus as a means of learning English language (Curriculum Development Centre, 2003). The English literature component is foregrounded in the Blueprint whereby it is seen as a tool and resource to enhance students' English language proficiency and their thinking. The incorporation of a tested literature component in the secondary school English syllabus made the point that the study of literature benefits language learners. The use of literary texts is known to have multiple benefits for learners in the English language classroom (Lazar, 1993; Erkaya, 2005; Chiang, 2007; Zaker, 2016; Fauziah, 2016). Lazar (1993), Erkaya (2005) and Chiang (2007) revealed that using literary texts as a language teaching resource can be beneficial in developing students' language development, personal growth and cultural enrichment as well as refining the students' thinking through their interpretation of the literary texts. Through the incorporation of the literature component in the English language instruction certain language skills among language learners, especially in developing their reading and writing skills can be enhanced (Saraceni, 2007).

As such, since teaching of literature is part of the English language syllabus and teachers have been directed by the Ministry of Education to use thinking maps in their English language lessons as a tool to enhance students' critical thinking, it would be interesting to discover the English language teachers' utilisation of thinking maps in their ESL classroom. Therefore, this paper examined the English language teachers' use of thinking maps to promote critical thinking among their students during the literature lessons. 


\section{1 i-Think Program in Malaysia}

The i-Think program involves teachers having to use thinking maps as a tool in their lessons which hopes to promote critical thinking in their students both in Primary and Secondary schools throughout the country. The i-Think program has three main objectives:

i. Nurture and develop innovative human capital

ii. Increase thinking skills amongst children

iii. Equip future generations with Higher Order Thinking Skills (HOTS)

The i-Think or Thinking Maps program consists of eight maps that correspond with fundamental thinking processes. The Circle Map is used for defining in context; the Bubble Map, describing with adjectives; the Flow Map, sequencing and ordering; the Brace Map, identifying part/whole relationships; the Tree Map, classifying/grouping; the Double Bubble Map, comparing and contrasting; the Multi-Flow Map, analyzing causes and effects; and the Bridge Map, seeing analogies. These maps are a common visual language for students in all subject areas (Hyerle, 2000). Hyerle (2000) believes that thinking maps are visual teaching tools that provide students with the skills to be successful thinkers, problem solvers, and decision makers.

Teachers were trained under Malaysia's National Innovation Agency, a key government agency reinventing the country's schools. The Ministry of Education hopes that all 10,000 schools would implement the i-Think program by 2014 (New Straits Times, 2012). The program is part of the national education transformation plan to create a thinking and creative younger generation with the view of the students being innovative, analytical, able to adapt to crisis, throw ideas, think outof-the-box and able to solve problems. In accordance with this plan, the skills will be incorporated into the modules at the teacher training institutes to prepare new teachers to handle the programme (Nooraini Othman \& Khairul Azmi Mohamad, 2014).

\section{Literature Review}

Critical thinking is one of several learning and innovation skills necessary to prepare students for the $21^{\text {st }}$ century as well as for the workforce. Critical thinking is believed to include the component skills of analyzing arguments, making inferences, judging or evaluating, and making decisions or solving problems (Paul \& Elder, 2007). Bassham, Irwin, Nardone \& Wallace (2007) define critical thinking as follows:

"critical thinking is the general term given to a wide range of cognitive skills and intellectual dispositions needed to effectively identify, analyse, and evaluate arguments and truth claims, to discover and overcome personal prejudices and biases, to formulate decisions".

(Bassham et al.,2007,p.58) 
Critical thinking skills are learned in the English language classroom through reading, writing speaking, listening, viewing, and visual literacy to help students to progress beyond the four walls of the classroom (Chittooran, 2015). Students entering the $21^{\text {st }}$ Century should be equipped with thinking skills so that they will be able to be self-initiating, self-modifying and self-directing (Costa, 2001). The term critical itself refers to a property owned by someone to argue, conclude and bring a decision based on facts or information which has been analysed. Also taken into account in critical thinking are elements such as the clarity, accuracy, suitability, consistency, logical correctness / logicalness, deep depth and breadth / completeness, fairness and the significance of an argument significance (Richard, 2001). Critical thinking is the efficiency and the ability to use the mind to assess the reasonability or fairness of an idea, and making judgment by using reason and reasonable evidence. One technique to improve creative thinking skills is through brainstorming techniques. This technique is used to solve a specific problem in which a set of good ideas, fresh and new, as well as to generate more ideas ( Ruggerio, 2007). Emerson (2013) and Heijltjes, Gog, \& Paas (2014) contend that teaching critical thinking can explicitly promote students' ability in analysing subject matters based on contextualization and at the same time can implicitly improve students' thinking skills as well.

The definition and the intellectual dispositions on critical thinking is applicable to the i-Think program whereby the Thinking Maps or visual tools can provide the students with the ability to think critically as apart from generating ideas, which require analysis and evaluation, they also need to collectively come to the right decision to solve their problem in the task. As such, the i-think program does promote critical thinking processes when students are participating in the Thinking Map activities. Bloom's (1956) Taxonomy of Educational Objectives identified analysis, synthesis and evaluation as higher order thinking processes and defined each of these terms explicitly in his Taxonomy. Anderson and Krathwohl (2001) updated Bloom's Taxonomy where they defined higher order thinking as design, construction, and metacognition. Higher order thinking was defined as a function of intellectual activity in the knowledge and/or cognitive dimensions. The authors highlighted that within the knowledge dimension, thinking skills included factual, conceptual, procedural, and metacognitive knowledge. Anderson and Krathwohl (2001) further reiterated that the cognitive dimension included remembering, understanding, applying, analyzing, evaluating, and creating knowledge, with creating knowledge identified as the highest order of thinking thus enabling students to become critical thinkers.

The Thinking Maps are based on eight fundamental cognitive skills which are: defining in context, describing attributes, comparing and contrasting, classification, part-whole spatial reasoning, sequencing cause and effect reasoning and reasoning by analogy (Hyerle, 2009). All these skills and cognitive processes involve students in critical thinking and this is exemplified in the Thinking Maps. For example, when students are involved in the cognitive process of comparing and contrasting, they may need to compare items or ideas to determine which category these items belong 
to and for what purpose. The cognitive processes that work together (compare and contrast) enable students to think at the higher level of Bloom's taxonomy. Thus, the implementation of the i-Think program can enhance as well as reinforce critical thinking in students and build on their capacity to become critical thinkers. As such, in order to cultivate critical thinking, English language teachers have to motivate students towards how to think instead of what to think in the English language lessons. If they could be taught to think critically in English language, it will enhance their abilities to read, write and think with clarity in that language (Ponniah, 2007).

Teachers need to teach students how to think critically and one of the ways is to teach them to interpret literary texts as literature is an effective tool for engaging students in critical thinking. As the teaching of literature is incorporated in the English language syllabus, teachers can take this opportunity to develop critical thinking by teaching the students how to analyse and evaluate the literary texts which involves them in seeing relationships between events, drawing inferences, analysing events, synthesizing evidence and evaluating the text. In the teaching of literature, teachers can use the Reader-Response Theory which is a first step in teaching critical thinking. Reader Response Theory offers limitless ways as to how a text can be explored especially in Malaysian teaching and learning context (Shahizah, Nackeeran, 2003). Tucker (2000) in his article, Liberating Students through Reader-Response Pedagogy in the Introductory Literature Course, concurs that the reader-response approach allows students more latitude in responding to what they read and encourages varied responses hence developing students' critical thinking. A reader-response approach focuses on students' individual responses to text and how he or she brings meaning to the text through his or her interpretative skills (Galda \& Liang, 2003). Ross C. Murfin in Tucker (2000) explains that Reader Response criticism focuses on what texts do to - or in- the mind of the reader, rather than regarding a text as something with properties exclusively its own. This approach enables students to experience relevance in the reading task, involves them in an active, not passive, encounter with the literature, validates them as critical readers who are capable of determining meaning in texts, and provides them with the opportunity to express themselves freely (Tucker, 2000).

According to Chiang (2007) mentioned that using literature as an authentic source in language classes provides ample opportunities for students to practice as well as improve the four language skills. His views was supported by Stern (2001) who points out that literature can be an being an ideal source for writing tasks as ideas and views can be generated through discussions on the different elements of literary texts such as characters, plots and themes. Ganakumaran (2012) highlights the fact that the education system keeps bringing back literature into the syllabus was because literature is 'a question minus the answer' where it helps students to generate discussion, controversy and critical thinking. There are extensive reasons of why literature should be incorporated in the language classroom. Some of the reasons that may perfectly fit the objectives of this study are that literature develops perceptive and interpretative thinking skills and through the use of thinking maps, 
students' existing thoughts are challenged as they are required to understand, interpret and analyse the texts in order to complete the thinking maps provided to them. Chiang (2007, p. 170) mentioned "Literary texts are often rich is multiple layers of meaning, and can be effectively mined for discussions. While literature has the potential to be a tool of great use in L2 classrooms, its potential can be best realized when readers are encouraged to develop personal responses to the reading from multiple aspects and to share them in discussions". Responding and reacting to the tasks given in the form of thinking maps would enhance the students' critical thinking.

The emphasis on developing critical thinking needs to be emphasized in the classroom. Odenwald (2010) explains that students should be given the opportunity to voice their opinions so that their intellectual enrichment and confidence is built. Once the students are confident, they will be able to share and create meaning with their classroom community through active discussions. The challenge is to get students to believe in what they are saying, and look beyond the text and the teaching of literature can do just that. According to Jensen (in Hyerle, 2012) in his book Brain-Based Teaching and Learning, ninety per cent of all the information coming into the brain is in visual form. The benefit is that thinking maps are concrete illustration of abstract concepts associated with our ability to learn visually and how to complete the map and processing complex structure of our visual context. Maps allow the brain to think of a visual pattern, since it is created with both the teaching and learning. Tasks or activities given to students should be more complex and challenging so that students would be able to solve any problems by using critical thinking skills (Kuh, 2001). Most students do not have a high level of skills (Weimer, 2003) and as such, critical thinking skills must be implicated in the curriculum and syllabus so that students have the opportunity to practice them (Ewing, 2006) and this is actually associated to the use of thinking maps in the English language lessons.

\section{Research Methodology}

The study employed a case study approach as the researcher focussed the study on three English language teachers in a school teaching literature during their English language lessons. The participants for the study are trained teachers in the field of Teaching of English as a Second Language (TESL). Data were obtained through observations, structured interviews and field notes. Based on six observations done on one teacher teaching form one class, data was analysed on how the teacher employed the thinking maps in her literature lessons.

A structured interview was conducted on the three English language teachers and their responses were recorded in writing directly on the copy of the interview guide. The important responses in form of excerpts were extracted from the interview guide to represent the findings to the research questions. This study focuses on the following research questions:

1. How are the thinking maps used to promote critical thinking during the teaching of literature in the ESL classroom? 
2. How do English language teachers perceive the use of thinking maps to promote critical thinking during the teaching of literature in the ESL classroom?

\section{Findings}

The first research question involved exploring the utilisation of thinking maps to promote critical thinking in the literature lessons whereby the analysis of findings is presented in the form of a flow chart. The findings for this research question were derived from the researcher's observation of an English language teacher's use of thinking maps during her teaching of literature lessons through the use of an observation protocol. The qualitative data based on six observations done of the teacher's use of thinking maps in her lessons is summarised in the flow chart below.

Figure 1: Flow chart on the use of thinking maps in a Form One Literature Lesson

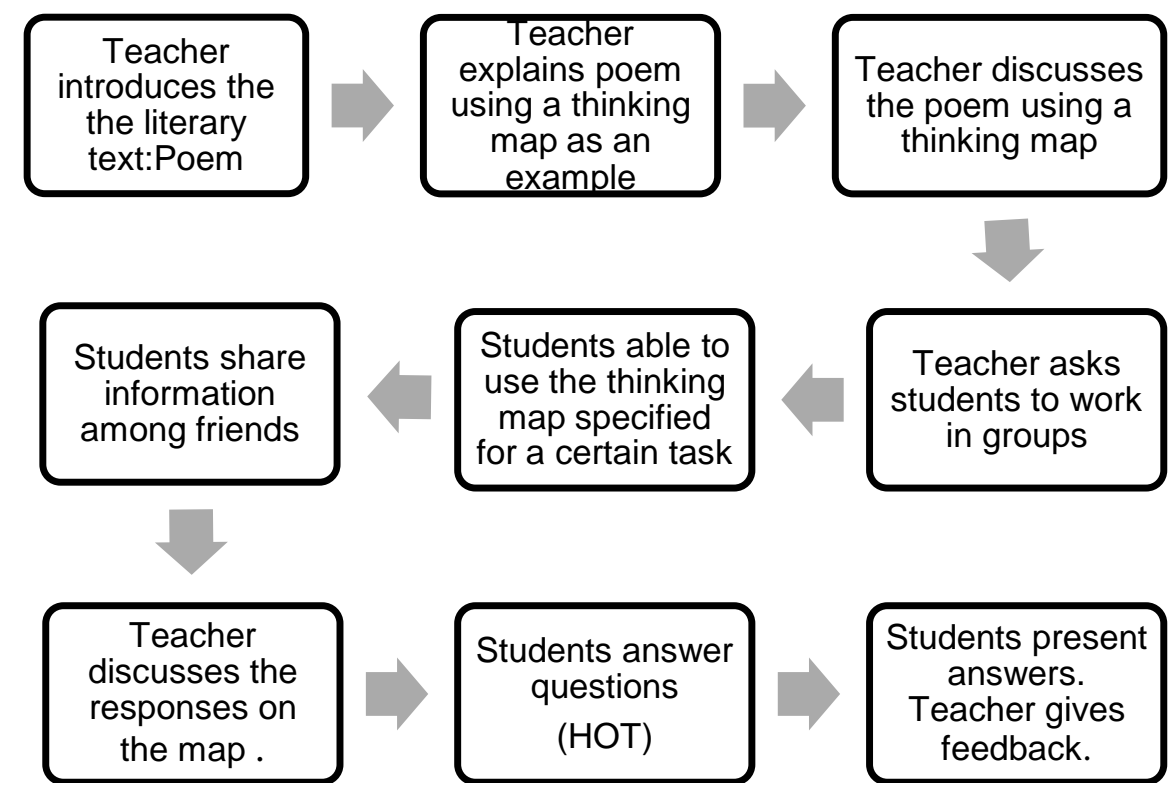

The English language teacher's (Teacher A) lessons took place four times a week. Teaching a form one classroom, Teacher A uses thinking maps in most of her literature lessons. In all her lessons, Teacher A would start her lesson by introducing the topic for the day to her students. Then the teacher would show a thinking map to the students and explain the content of the lesson through the thinking map. This would be her input or explanation stage. During the explanation stage, the teacher would use thinking maps as an example to highlight the learning points for the day. An example would be using a circle map to describe the vocabulary in the poem.

For the practice stage, teacher A divided the students into groups of five and each group were given a task of preparing a circle map and tree map on the poem (Best Things by Eric Finney). After the students have completed the task, they volunteered to present their thinking maps to their classmates. This was followed with a discussion between the teacher and the students. At this point, the teacher asks high 
order thinking questions such as "why do you think the title of the poem is Best Things? Do you think this is a good title for the poem? What other titles could you give this poem? Why?" After the discussion, students were instructed to answer a few questions written on the board by the teacher. Finally, the teacher selected students randomly to answer the questions and teacher gave feedback when necessary.

During the observations, the researcher found that when the teacher used the thinking maps as a reference to explain the content of the topic with examples, students were able to understand the topic and this was evident when they used the thinking maps in presenting the task given to them. The thinking maps provided opportunities for them to generate ideas as well as justify their answers. Although the students took some time to discuss and complete the maps they were involved in the thinking process of generating ideas. The discussion questions which followed after the students presented their maps provided opportunities for students to provide their interpretations and response after reading the poem. The teacher had actually resorted to the Reader-Response Theory in order to enhance further the students' critical thinking.

\section{Figure 2: Samples of Students' Thinking Maps}

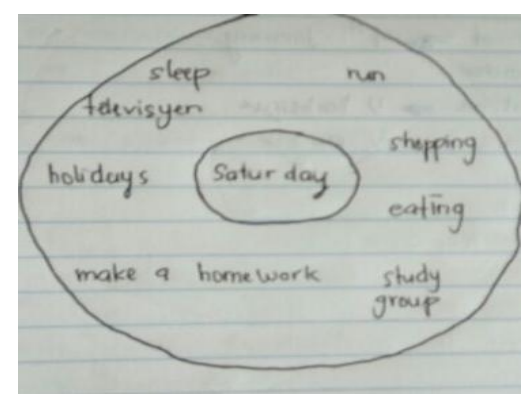

Student's Circle Map

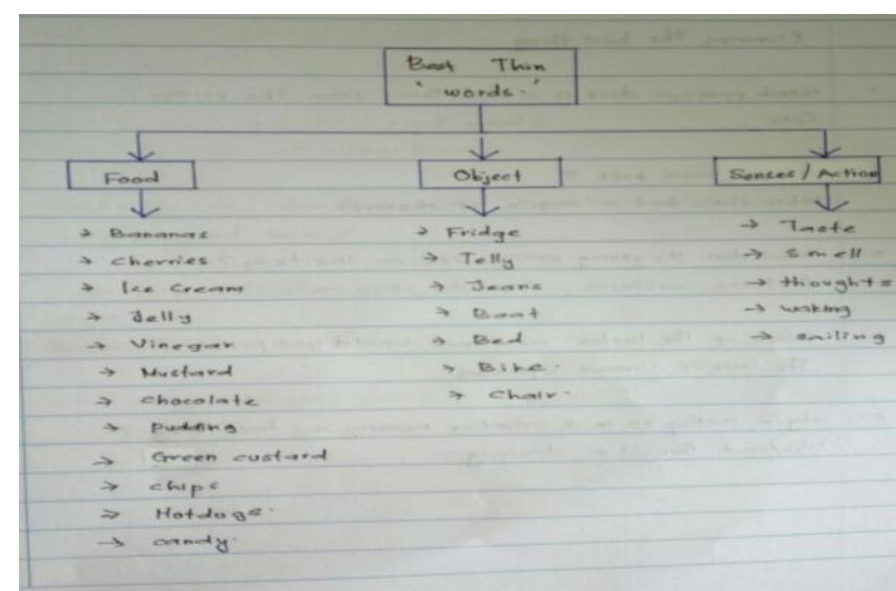

Student's Tree Map

Interview data with the teacher supported her utilization of the thinking maps in her literature lessons The first interview question, which was her selection of i-Think map to use with her students in her literature lessons, indicated that her choice was based on the topic and learning outcome. She stated that normally she would ask her students to complete worksheets after teaching but currently, she decided to use the thinking maps to get students involved in the learning. She offered the following comments:

TA $\quad: \ldots$ it depends on the topic and the learning outcome. For example, the learning outcome is for them to understand the literal and underlying meaning of the poem so I chose the circle map and also the tree map. I use it... so teach students to think. When they present their maps, it shows 
they understand and they can justify their answer...that's good.

Findings from both the observations and interview with the teacher revealed that the teacher saw the benefits of exploiting thinking maps in her lessons especially so in the generation of ideas and understanding the literary elements as well as assisted students in gaining confidence in using the English language. When asked about the higher order thinking questions using the Reader-Response strategies, the teacher responded as follows:

TA : Oh..its Reader-Response strategies? I just thought that I'll ask some synthesizing and evaluative questions. As you can see, the students can answer but with guidance from me...they are still new to this higher order thinking questions actually...but I try and they also try... which is good.

Pertaining to the teachers' perceptions of the utilization of thinking maps in the literature lessons, the interview data embraced the following themes:

i. implementation of thinking maps in literature lessons;

ii. effectiveness of the thinking maps in literature lessons

In the interview, the teachers revealed that they had attended training on the i-Think program and have implemented the thinking maps in their English language classrooms especially for the teaching of literature.

TA : Yes, I do have knowledge about the eight thinking maps. I attended a course at Ministry level and school level. I think the courses are important so that I know how to teach my students using the thinking maps.

The teachers also gave their views on the regularity of utilising the thinking maps in their lessons and voiced their reservations about implementing the thinking maps in all their English language lessons. However, they do utilize the thinking maps in their literature lessons. They made the following comments:

TB : It takes time for my students to complete the maps so I don't use it very often...sometimes once or twice a week. I use it mostly for my writing lessons and most of the time for my literature lessons. They can generate ideas using the double bubble map, circle map and flow map.

The teachers also commented that there seemed to be a positive development in their students' understanding of the literary texts after they utilised the thinking maps with their students. The students were able to generate and organise their ideas and seemed to portray more confidence in using the language.

TC : It's useful for understanding the poems and short stories...for example, they can write their own ideas and organise the ideas...they can use circle maps. So their understanding of the poems and short stories has 
improved and they are more confident to use the language when they discuss their topic.

The findings showed that the teachers have relevant knowledge of the thinking maps and acknowledged that they do utilize the thinking maps in their English language lessons. They found the use of the thinking maps in their literature lessons to be beneficial and effective to their students learning the language.

\section{Discussions and Conclusion}

Connor-Greene and Greene (2002) stated that critical thinking is an essential skill for living in the information age and as such the Malaysian Education system has followed the trends to design policies and curriculums for education reform to produce the next generation for the global workforce. The National Education Blueprint (PPPM) 2013-2025 highlights the importance of high level thinking skills which is translated in the i-Think program whereby teachers are encouraged to use thinking maps in their lessons. The study investigated the teachers use of the thinking maps to promote critical thinking in the teaching of literature in the ESL classroom. Findings indicated that the teachers have utilised purposeful and explicit approaches to teaching with Thinking Maps and that seemed to have a positive impact on students' understanding of the literary texts as well as English language development among the students.

This is important as explicit instruction or teaching involves directing student's attention toward specific learning that focuses on producing specific learning outcomes and this involves explanation, demonstration and practice (Hall, 2002). Knowledge about the Thinking Maps is important as the building of thinking skills among students can be jeopardized due to the fact that the teachers are not highly skilled in transforming the skills from the classroom teaching (process) to the students (application) (Nooraini Othman \& Khairul Azmi Mohamad, 2014).The teacher's implementation of the thinking maps in their literature lessons indicated positive outcomes as findings demonstrated that the use of thinking maps promotes the generation of ideas, improved students' written and oral language and built their confidence in presentations. The teachers also resorted to using the Reader-Response strategies when they posed questions about the literary texts to the students. The students' responses showed they were confident when giving their opinions as they became personally involved in the interpretation of the literary text. The reader Response strategies allow teachers to create activities that can guide students to think critically about what they read (Garzón \& Castañeda-Peña, 2015). Literature reading is important to the essential traits of critical thinking as the mental process of literature reading requires critical thinking skills. Literature reading is a complex process that requires readers to recall, retrieve and reflect on their prior experiences or memories to construct meanings of the text and through the use of thinking maps, students demonstrate the process of critical thinking.

The i-Think program was introduced as part of the national education transformation plan to create a thinking and creative younger generation in view that they will be innovative, think out-of-the-box and able to solve problems. Thus, its 
implementation is seen as an important and significant change needed to meet new challenges of creating a "thinking culture" in schools and this change is a huge responsibility for teachers in the new concept of learning in the $21^{\text {st }}$ century.

\section{References}

Amin Senin (2013). Creating knowledgeable students through critical thinking. Retrieved from news@nst.com.my

Anderson, L.W., \& Krathwohl, D.R. (Eds.) (2001). A taxonomy for learning, teaching, and assessing: A revision of Bloom's Taxonomy of educational objectivist. New York: Longman.

Bassham,G., Irwin, W., Nardone, H. \& Wallace, J.M. (2007). Critical Thinking: A Student's Introduction $\left(5^{\text {th }}\right.$ Ed). New York: McGraw Hill International Edition.

Bloom B. S. (1956). Taxonomy of Educational Objectives, Handbook I: The Cognitive Domain. New York: David McKay Co Inc.Gardner

Chiang, M. (2007). Improved reading attitudes and enhanced English reading comprehension via literature circles. Lagos Papers in English Studies, 1(1), 168-183

Chittooran, M. M. (2015). Reading and writing for critical reflective thinking. New Directions for Teaching \& Learning, (143), 79-95.

Connor-Greene P. A., Greene D. J. (2002). Science or snake oil? Teaching critical evaluation of "research" reports on the Internet. Teaching of Psychology, $29,321-324$

Costa, A. (2001). Developing minds. Alexandria, VA: ASCD.

Curriculum Development Center. (2003). Curriculum specifications for English. Kuala Lumpur: Dewan Bahasa dan Pustaka.

Emerson, M. K. (2013). A Model for Teaching Critical Thinking. Online Submission. Available at: http://eric.ed.gov/?id=ED540588 (Retrieved on Dec 23, 2015).

Erkaya. O.R. (2005). Benefits of Using Short Stories in the EFL Context. Asian EFL Journal. Volume 8, 1 - 13

Fauziah, F. (2016). The Approaches to Teaching Literature for EFL Young Learners. Journal of English Language Teaching and Linguistics, 1(2), 2016. DOI: http://dx.doi.org/10.21462/jeltl.v1i2.26

Galda, L., \& Liang, L. A. (2003). Reading as experience or getting the facts? Stance and literature in classrooms. Reading Research Quarterly, 38(2), 268-275.

Garzón,E. \& Castañeda-Peña, H. (2015). Applying the Reader-Response Theory to Literary Texts in EFL-Pre-Service Teachers' Initial Education. Canadian Center of Science and Education 8(8), 187-198

Hall, T. (2002). Explicit instruction: Effective classroom practices. Retrieved on 2 December 2015 from http://www.pearsonassessments.com/research

Heijltjes, A., Gog, T. V., \& Paas, F. (2014). Improving Students' Critical Thinking: Empirical Support for Explicit Instructions Combined with Practice. Applied Cognitive Psychology. Available at: www.wileyonlinelibrary.com (Retrieved on Dec 24, 2015) 
Hyerle, D. (2009). Visual tools for transforming information into knowledge (2nd ed.).

Hyerle, D. (2000). A Field Guide to Using Visual Tools, ASCD, Association for Supervision and Curriculum Development.

Hyerle, D. (2012). Student successes with thinking maps. Thousand Oaks, CA: Corwin.

Khatib, S. (2011). Applying the reader-response approach in teaching English short stories to efl students. Journal of Language Teaching and Research, 2(1), 151159.

Kuh, G. D. (2001). Assessing What Really Matters To Student Learning: Inside The National Survey of Student Engagement, Change: The Magazine of Higher Learning, 33, (3): 131-137.

Lazar, G (1993). Literature in the Language Classroom. Cambridge: Cambridge University Press, $180-185$ in

Ministry of Education, Malaysia. (2013). Malaysia Education Blue-print 2013: Preliminary Report 2013-2025. Retrieved December 10, 2013, from http://www.moe.gov.my/en/pelan-pembangunan-pendidikan-malaysia-20132025

Nooraini Othman \& Khairul Azmi Mohamad (2014). Thinking Skill Education and Transformational Progress in Malaysia. Journal of International Education Studies; Vol. 7, No. 4. Published by Canadian Center of Science and Education Press.Thousand Oaks, CA: Corwin Press.

Odenwald, K. (2010). Transforming liberal education through the imagination: Critical creative thinking in higher education curriculum and pedagogy. ProQuest Dissertations and Theses (305185666).

Paul, R., \& Elder, L. (2007). Critical thinking concepts and tools (5th ed.). Dillon Beach, CA: Foundation for Critical Thinking.

Ponniah, R. J. (2007). A Constraint for Integrating Critical Thinking Skills Into Indian ESL Classrooms. Language in India. Vol. 7 Issue 7, p2-2. 1p.

Ruggiero,V.R.(2007). The Art of Thinking. (8th ed). Boston:Pearson Education, Inc.

Saraceni, M (2007). Literature in the EFL Classroom : Roses or Thorns? in Teaching of Literature in ESL/ EFL Context. Kuala Lumpur, Malaysia : Sasbadi Sdn. Bhd.

Stern, S. L. (2001). An integrated approach to literature in ESL/EFL. In CelceMurcia (Ed.), Teaching English as a second or foreign Language (pp. 328345). Boston, MA: Heinle \& Heinle.

Tucker, L.P (2000). Liberating Students through Reader-Response Pedagogy in the Introductory Literature Course. Copyright by the National Council of Teachers of English : 199 - 209

Weimer, M. (2003). "Focus on learning, transform teaching". Change 35 (5), 48 (7). Retrieved December 4, 2015, from Expanded Academic database.

Zabani, D. (n.d.). Status Pencapaian Malaysia Dalam TIMSS dan PISA: Satu Refleksi Dr Zabani Bin Darus KPM 2012.Retrieved December 4, 2015, from http://education.um.edu.m...201/(1) Dr Zabani.pdf 
Zaker, Alireza. (2016). Literature and Creativity in an ELT Context. ASIAN TEFL, $1(2), 2016$

\section{Keynote Speech}

Subramaniam, G (2012). Literature \& English Language Education: What art thou?.Keynote speech during a Seminar ESL Academic Discourse: Literature in English. Universiti Pendidikan Sultan Idris Perak. 20 October 2012 